Inger Askehave \& Karen Korning Zethsen*

\title{
Medical texts made simple - dream or reality?
}

\begin{abstract}
This article is concerned with some of the problems medical companies have in trying to produce user-friendly medical texts. Research has shown that consumer information within the medical field is often difficult to understand for the non-specialist. There are several reasons for this. One is the frequent use of special language features in texts concerned with consumer information. This article discusses the advantages and disadvantages of special language and suggests ways in which specialist words and expressions may be downgraded and simplified in order to accommodate the intended non-specialist target group.
\end{abstract}

\section{Introduction}

"In that case," said the Dodo solemnly, rising to its feet, "I move that the meeting adjourn, for the immediate adoption of more energetic remedies -“"

"Speak English!" said the Eaglet. "I don't know the meaning of half those long words, and, what's more, I don't believe you do either!"

(Alice in Wonderland)

The study of functional variations of language is an area of linguistics which has received considerable attention since its introduction in the 1960s. Different approaches have been adopted to throw light on the way language varies as its function varies - moving from an identification of statistically significant linguistic properties of language varieties (Halliday et al. 1964) to a concern with communicative purpose of language varieties (genres) (Bhatia 1993, Swales 1990). This article also contributes to the study of functional variations of language. However, whereas recent studies on language varieties 'attempt to describe and explain the rationale underlying various professional and academic genres' (Bhatia 1993: 13), the aim of this article is not to characterise

* Inger Askehave \& Karen Korning Zethsen

Department of English

The Aarhus School of Business

Fuglesangs Allé 4

DK-8210 Aarhus V

Hermes, Journal of Linguistics no. 25 - 2000 
yet another genre. Instead we would like to draw attention to the difficulties of varying language use according to context. More specifically we shall be concerned with the problems medical companies have in trying to adjust their language use to a non-specialist target group in order to produce user-friendly medical texts.

\section{Background}

The medical text, which we will be concerned with here, is the so-called patient package insert (PPI). Patient package inserts are a fairly recent phenomenon in a Danish context. As a result of EU legislation it became a requirement in Denmark in 1993 to include product information - the patient package insert - in all packages containing medical products aimed directly at the consumer. This did not happen overnight, but since 1993 no new marketing approval has be issued without a PPI.

The PPI has been made a legal requirement in order to inform and protect the consumer and the law is quite specific:

"The package leaflet [PPI] must be written in clear and understandable terms for the patient and be clearly legible in the official language or languages of the Member State where the medicinal product is placed on the market."

(Council Directive 92/27/EEC of 31 March 1992 - article 8)

The problem, however, is that many Danish PPIs are not clearly legible and the PPIs often confuse and even frighten the consumer instead of informing and protecting him.

In Askehave \& Zethsen (in press) we discussed the preliminary results of our research project concerned with the readability or userfriendliness of PPIs from the point of view of the consumer. Here we attributed the lack of user-friendliness in PPIs to the following factors:

(i) inter-linguistic translation

(ii) inter-generic translation

Inter-linguistic translation is concerned with translation between languages - for example when an English PPI is translated into Danish. Inter-generic translation is concerned with translating one genre into another genre ${ }^{1}$ and this concept is used to refer to the fact that PPIs

1 For a theoretical discussion of inter-generic translation, see Askehave/Kastberg (in press). 
must be drawn up in accordance with another genre, the so-called product summary (PS). In this article we shall focus on one aspect of inter-generic translation - more specifically the linguistic problems caused by the need to shift from specialist information in the PS to consumer information in the PPI.

\section{Inter-generic translation - the relation between the PS and the PPI}

The PS is a medical text which provides the authorities approving a medical product for marketing with all the information available on the product. As mentioned above EU legislation requires a close relation between the PS and the PPI in terms of content:

"The package leaflet [PPI] shall be drawn up in accordance with the summary of the product characteristics [PS]."

(Council Directive 92/27/EEC of 31 March 1992 - article 7)

The relation between the PS and the PPI is basically a good idea. The authorities/legislators want to make sure that consumers get the same information about the medical product as the specialists within the field. They want to avoid that dangerous side effects are neglected in the insert and that other types of vital information are kept a secret in order to persuade the patient to prefer one brand to another.

However, the required relation is also problematic and could be seen as one of the reasons why PPIs are not particularly user-friendly. The reason is that the above requirement is met to such an extent that not only content but also form is directly transferred from the PS to the PPI. Thus even though EU law stipulates that the linguistic realisations in the two genres should not be identical (viz - "The package leaflet [PPI] must be written in clear and understandable terms for the patient and be clearly legible in the official language or languages of the Member State where the medicinal product is placed on the market."(Council Directive 92/27/EEC of 31 March 1992 - article 8), the medical companies often transfer medical words and expressions directly from the PS to the PPI. In other words, the text producers do not pay attention to the fact that the change in target group (from specialists in the PS to non-specialists in the PPI) requires a.o. a downgrading of special language features. And the result is clear enough; consumers find it difficult to read and consequently use the inserts. 
Before we move on to providing examples of how the PPIs use special language features normally associated with specialist to specialist communication, it would be relevant, however, to briefly consider the concept of special language communication and special language characteristics.

\section{Special language communication}

When two specialists communicate within a special knowledge domain they will more often than not use what we refer to as special language. Many scholars have tried to define special languages establishing, at least for pedagogical reasons, a division between special language and general language (see Bergenholtz \& Engberg 1995: 182-184, Sager et al. 1980: 1). Following Halliday (1994) and Sager et al. (1980), we suggest that special languages and general language are two sides of the same coin:

"The difference between general and special language is a difference of degree rather than kind: the degree to which the fundamental characteristics of language are maximised or minimised in special language."

(Sager et al. 1980: 17)

Thus if we regard language (the language system) as 'a resource for making meaning' (Halliday 1994: xxvi), it follows that using language in a special context is not a question of inventing a new language but rather a question of choosing among the vast range of linguistic choices which the language system places at our disposal. Depending on extralinguistic factors, such as the pragmatic function and the context of situation, we make appropriate choices from the language system. And over time language varieties (e.g. 'special languages') evolve as particular linguistic choices become conventionalised and associated with a particular context and function.

Sager et al. (1980: 69) define special language in the following way:

"Special languages are semi-autonomous, complex semiotic systems based on and derived from general language; their use presupposes special education and is restricted to communication among specialists $^{2}$ in the same or closely related fields."

2 For a criticism of the restriction of special language to specialist communication only, see Aitken (2000). 
Thus as people acquire knowledge of a special field (e.g. medicine), they learn to communicate with peers using the linguistic tools appropriate in the special context. Therefore when a pharmacist is asked to describe the side effects of a medical product in the product summary (intended for another specialist) he obviously uses special language, i.e. words and expressions associated with the particular field of medicine - for example:

"Cases of lactic acidosis, usually associated with severe hepatomegaly and hepatic steatosis, have been reported with the use of nucleoside analogues."

(Epivir Product Summary 1996 - 'undesirable effects')

The non-specialist may have a hard time trying to decode the meaning of this sentence and estimate the side effects of the product prescribed by the doctor. However, the above expression is common, and expected, in a situation involving highly specialised communication between equals or near-equals in knowledge and professional role.

\subsection{Special language characteristics}

As it appears from the discussion above a definition of special language should not be based on the use of particular linguistic features. However, as special language maximises and minimises certain features of general language, it is possible to provide a description of the most frequent linguistic features ${ }^{3}$ used in special language texts (even though special languages are numerous and their characteristics are diverse). Traditionally technical texts are defined on the basis of subject-matter, terminology and a number of typical syntactic features ${ }^{4}$ such as:

Nominalisation

Heavy pre- and postmodifications

Extensive use of passives

Use of third person

Long sentences."

3 Though not necessarily the most important features as far as the aim of the text is concerned.

4 In addition to these very frequent syntactic features special language texts may of course make use of all sorts of rhetorical strategies and features (see Korning Zethsen 1997). 


\title{
4.2. Special language and the layman
}

As illustrated above special language is a perfect example of how wellequipped language is for addressing situations where e.g. a specialist explains the side effects of a medical product to another specialist. Problems arise, however, when the specialist is asked to explain the same phenomena to a non-specialist. This shift in target group evidently requires linguistic adjustments.

\begin{abstract}
"Depending on the pragmatic function and the context of situation, including the epistemiological factor, the same topic within a special field lends itself to discussion at different levels of abstraction. The degree of specialization reflects the pre-knowledge the receptor is assumed to possess."
\end{abstract}

(Varantola in Cabré 1999:76).

The notion of a special field with different levels of abstraction described in the quotation above is very relevant in the case of PPIs. The PPIs belong to the special field of medicine, more specifically that of medical products. However, whereas most medical texts are intended for other specialists, the PPI provides information about the product to laymen who have no pre-knowledge of the field as such. This change of extra-linguistic features (such as target group and function of the text), where we move from communication between equals to asymmetrical communication between specialist and non-specialist, calls for less complex language use at a lower level of abstraction.

However, most medical specialists find it difficult to adjust their special language to the target group of PPIs. The employees that work with the inserts in medical companies are usually pharmacists. They are experts who have the advantage of possessing expert knowledge within the medical field. And they have become so used to specialist vocabulary and expressions that they tend to use the same words and expressions in PPIs instead of explaining the medical concepts at a lower level of complexity. In other words the pharmacists lack the ability to downgrade their special language to accommodate the non-specialist target group. Thus instead of producing user-friendly information to consumers, they produce texts which in some parts are only accessible to people within the medical field. 


\section{Analyses}

We have analysed about 40 Danish inserts from app. 10 different medical companies. It appears from our analyses that most inserts use special language at a very high level of complexity. In the following we shall illustrate some of the difficulties the companies have in adjusting or, in this case, downgrading their special language to a non-specialist target group. At the same time we shall point to suggestions for improvement recommended to the Danish medical companies (see also Askehave \& Zethsen 2000).

In order to show how the PPIs use special language normally associated with specialist to specialist communication we shall focus on the use of potentially complex linguistic features such as special terminology, long and complicated sentences, nominalisations, premodifications and the passive voice 5 .

\subsection{Lexis}

\subsubsection{Special terminology}

One of the key characteristics of special language is the use of terms specific to a discipline. Such terms are closely related to the field of discourse and are normally used by specialists only. In our analysis of Danish PPIs we found that the use of special terminology was extremely widespread in the inserts. Thus we would find expressions such as:

Lokal ødemdannelse

Gramnegative baktier

Suspension

Hepatitis

Antiretroviral

Kontraindikationer

Anafylaktisk shock

Symptomgivende gastro-esofageal reflux

Gastroskopisk verificeret Helicobacter pylori-associeret mavesår

Sometimes, but far from always, the authors would try to alleviate the problem by providing a more common expression or simply paraphrase the special term in brackets:

5 There are numerous other examples of non-user-friendly language in the texts analysed, but they are not relevant for the present article on special language features (see Askehave \& Zethsen 2000). 
Enterokapsler (det aktive stof afgives først i tarmen og ikke i mavesækken)

Hypoglykæmi (dvs. for lavt blodsukker)

However, the fact that many inserts rely entirely on special terms results in severe comprehension problems; the non-specialist does not know what the terms mean.

We suggest that to reduce the level of complexity and thus adapt the language to the target group, the inserts should e.g. prioritise the common Danish expression 'leverbetændelse' instead of the Latin word 'hepatitis'. If for some reason it is deemed useful for the patient to know the Latin/medical term, it should be put in brackets the first time the common expression appears. In most cases the medical term is not relevant and may just as well be left out. And in those cases where no common term exists, a whole sentence should simply be produced - as in the following example:

Gastroskopisk verificeret Helicobacter pylori-associeret mavesår

We recommend the following wording:

'mavesår, der er konstateret ved kikkertundersøgelse, og som skyldes

bakterien helicobacter pylori'

Those adjustments would make language use less complex while the medical topic of the text as such remains unchanged.

Furthermore, the PPIs often suffer from the use of non-medical words and expressions which are very long, but do not mean a lot (officialese) - something which does not exactly add to the legibility of the text.

\subsubsection{False friends}

Another phenomenon common to medical language is the use of 'false friends', that is, words or expressions used in ordinary language, but which have developed a specialised meaning within medicine which means that the risk of misunderstandings is great.

\subsubsection{Synonyms}

Something which is just as unfortunate as the use of special terminology is when synonyms are scattered over the same text. The ordinary reader is not able to judge whether the words or expressions are synonymous and is easily confused: 
Regulere blodets glukosekoncentration/regulere blodsukkeret

Aktiv substans/det aktive stof/selve medicinen i xx

Naturally, the same word or expression ought to be used throughout the text.

\subsection{Syntax}

In terms of syntactic features in inserts, the lack of user-friendliness is of a somewhat different nature. Whereas special terms may be completely unknown to the consumer and may present an immediate obstacle to comprehension, most syntactic and grammatical features in inserts are in fact known to the consumer. The non-specialist does encounter nominalisation, passive voice etc. in less specialised texts as such syntactic features are features of general language as well. However, the frequency of particular complex structures makes the texts less accessible to the reader - simply because the complexity makes the texts more compact and difficult to digest.

\subsubsection{Long and complicated sentences}

In the PPIs there are many 'inflated' sentences:

'Selv om præparatet ikke er forsynet med advarselstrekant for trafikfarlige lægemidler, udelukker dette ikke, at nogle personer alligevel sløves af præparatet i en sådan grad, at evnen til forsvarligt at føre motorkøretøj eller betjene farlige maskiner påvirkes'

The information of the sentence could be given by means of a much shorter and more userfriendly sentence:

'Der er ingen advarselstrekant på medicinen. MEN det kan ske, at du alligevel bliver så sløv af medicinen, at du ikke bør køre bil eller betjene farlige maskiner.'

\subsubsection{Passive and impersonal style}

An extremely passive and impersonal style is common in PPIs. Passive voice, nominalisation and the avoidance of personal pronouns are very frequent features:

- passive voice

'Der skal udvises forsigtighed ved samtidig indtagelse af alkohol, da alkoholpromillen kan $\phi g e s$ ' 
We recommend the following wording:

'Du skal være forsigtig, hvis du samtidig drikker alkohol, da medicinen kan få din alkoholpromille til at stige' (the formal word 'indtage' has been replaced with the more common 'drikke')

- nominalisation

'Selvom ikke alle får disse bivirkninger, kræver de medicinsk vurdering, hvis de skulle opstå':

We recommend the following wording:

'Det er ikke alle, der får disse bivirkninger. Men hvis du gør, skal du gå til din læge'

- avoidance of personal pronouns

'Lægen rådspørges i tvivlstilfælde'

We recommend the following wording:

'Du kan spørge din læge, hvis du er i tvivl'

Of course passive and impersonal constructions should not be completely avoided in PPIs. However, in cases which require the patient to act (drink the solution, press the pump or ask his doctor), active expressions are called for.

\subsubsection{Too much information in one sentence}

Generally, PPIs are rather long, but it is not a good solution to try to 'cram' as much information as possible into each sentence. Often phrase after phrase is added before a full stop and contrary to the 'inflated' sentences above, these sentences contain too much relevant information:

'Hos patienter med tidligere moderate til svære symptomer på sæsonbetinget allergisk rinit kan forebyggende behandling med xx påbegyndes op til fire uger før den forventede start af pollensæsonen.'

We recommend the following wording:

'Hvis du før har haft megen høfeber, kan det være en god idé at begynde at bruge xx op til fire uger før du regner med, at høfeberen sætter ind. Dette vil have en forebyggende virkning.'

Frequently premodification makes the individual phrases difficult to understand: 
Sæsonbetinget allergisk hфsnue

Peroralt antidiabetisk lagemiddel

Gastroskopisk verificeret Helicobacter pylori-associeret mavesår

Symptomgivende gastro-esofageal reflux

These premodifications should be converted to sentences in their own right.

\section{Conclusion}

Even though the Danish law stipulates that PPIs must be written in clear and understandable terms for the patient - many inserts are clearly not able to meet these legal requirements. Our analyses show that one of the major obstacles to legibility is the pharmacists' inability to downgrade and simplify their specialist language in order to accommodate the nonspecialist target group of PPIs. Thus the inserts contain specialist terminology, officialese, complex syntactic features, and an impersonal and passive style which, when added together, have a very negative impact on the readability of PPIs. However, as it appears from our recommendations to the medical industry, it is in fact relatively easy to improve the readability of PPIs while preserving the medical content. So medical texts made simple? Yes, why not!

\section{References}

Aitken, M. (2000). Directives and Indirectness. The Semantics and Pragmatics of Instructional Discourse. PhD thesis. Copenhagen Business School.

Askehave, I. \& Kastberg, P. (in press). 'Inter-Generic Derivation - on the genealogy of an LSP text'.

Askehave, I \& Zethsen, K. Korning (2000). Fremtidens Indlagssedler. Report for the Danish Ministry of Health. Aarhus School of Business.

Askehave, I. \& Zethsen, K. Korning (in press). 'Inter-generic and Inter-Linguistic Translation of Patient Package Inserts'.

Bergenholtz, H. \& Engberg, J. (1995). 'Tendenser inden for den nyere fagsprogsforskning i Danmark'. In Hermes 15. 179-206. Aarhus School of Business.

Bhatia, V.K. (1993). Analysing Genre: language use in professional settings. London: Longman.

Cabré, M. T (1999). Terminology. Philadelphia/Amsterdam: John Benjamins Publishing Company.

Carroll, L. (1929/1987). Alice's Adventures in Wonderland - Through the LookingGlass and other Works. London: Marshall Cavendish Partworks Ltd. 
Council Directive 92/27/EEC of 31 March 1992 on the labelling of medicinal products for human use and on package leaflets.

Epivir product summary. 08-1996. Glaxo Group Ltd.

Halliday, M.A.K. (1994). Introduction to Functional Grammar (2nd ed). London: Edvard Arnold.

Halliday, M.A.K., McIntosh, A. \& Strevens, P. (1964). The Linguistic Sciences and Language Teaching. (Longman Linguistics Library). London: Longman.

Sager, J.C. Dungworth, D. \& McDonald P.F. (1980). English Special Languages. Principles and practice in science and technology. Wiesbaden: Oscar Brandstetter Verlag.

Swales, J.M. (1990). Genre Analysis - English in Academic and Research Settings.

Cambridge: Cambridge University Press.

Varantola, K. (1986). Special Language and General Language: Linguistic and Didactic Aspects. ALSED-LSP Newsletter 9, 2 (23). 10-19.

Zethsen, K. Korning (1997). Expressivity in Technical Texts - from a Translation Theoretical Perspective. PhD thesis. Aarhus School of Business. 